\title{
Observations on Erysiphe platani in Germany
}

\section{Kirschner $\mathbf{R}^{*}$}

Department of Life Sciences, National Central University, Jhongli City, 320 Taoyuan County, Taiwan R.O.C.

Kirschner R. 2011 - Observations on Erysiphe platani in Germany. Plant Pathology \& Quarantine 1(2), 115-119.

The powdery mildew Erysiphe platani was recorded on London plane (Platanus $\times$ acerifolia) in Germany. Ascomata and conidia were found on a leaf of a tree at an avenue in the city of Frankfurt am Main, which had also been colonized by the invasive Sycamore Lace Bug Corythucha ciliata. The spread of both invasive species from south Europe towards the north might be correlated with global warming. Difficulties in detecting and identifying the mildew as the causative agent of the symptoms are presented. Information relevant for the diagnosis and prognosis is compiled and discussed.

Key words - Ascomycota - Erysiphales - invasive animals and fungi - Oidium

\section{Article Information}

Received 15 September 2011

Accepted 22 September 2011

Published online 2 October 2011

*Corresponding author: Roland Kirschner - e-mail - kirschner@ncu.edu.tw

\section{Introduction}

London plane (Platanus $\times$ acerifolia (Ait.) Willd.) is a very common ornamental tree planted in public places and along avenues in Germany. It is considered hybrid between $P$. occidentalis and $P$. orientalis (Carpenter et al. 2005), for which different scientific names are commonly used (Santamour \& McArdle 1986).

A major reason for preferring the hybrid as an ornamental as compared to its parent species is the larger resistance to anthracnose caused by the ascomycete Apiognomonia veneta (Sacc. \& Speg.) Höhn. (Diaporthales, as Gnomonia platani, Santamour \& McArdle 1986).

Platanus species also suffer from parasitic organisms, such as the invasive Sycamore Lace Bug Corythucha ciliata (Say) which has spread to London planes in Germany (Fig. 1). The insect was first introduced from North America to Italy in the 1960s and has been reported from Germany since the 1980s.

The powdery mildew Erysiphe platani (Howe) U. Braun and S. Takam., also a pathogen restricted to species of Platanus in North
America, has been introduced to South America, South Africa, Australia, New Zealand, Asia, and also to several European countries (Braun 1987, Pastirčáková \& Pastirčák 2006). In Europe, the fungus has been recorded mainly from countries in the south and southeast (ISC 2011), beginning in Italy in the 1960s according to the historical outline by Pastirčáková \& Pastirčák (2006), but not from Germany. This powdery mildew is reported here from Frankfurt am Main and remarks on difficulties encountered in differentiating the symptoms caused by this pathogen from those caused by other reasons are noted. A detailed account of the species with focus on the epidemic spread in Germany, the morphology of the anamorph and the phylogenetic position using rDNA sequence data will be presented in another publication considered for Andrias, a journal of Staatliches Naturkundemuseum Karlsruhe, Germany (Scholler et al. in prep., M. Scholler, pers. comm.). The phytopathological focus with emphasis on the teleomorph justifies a separate publication here. 


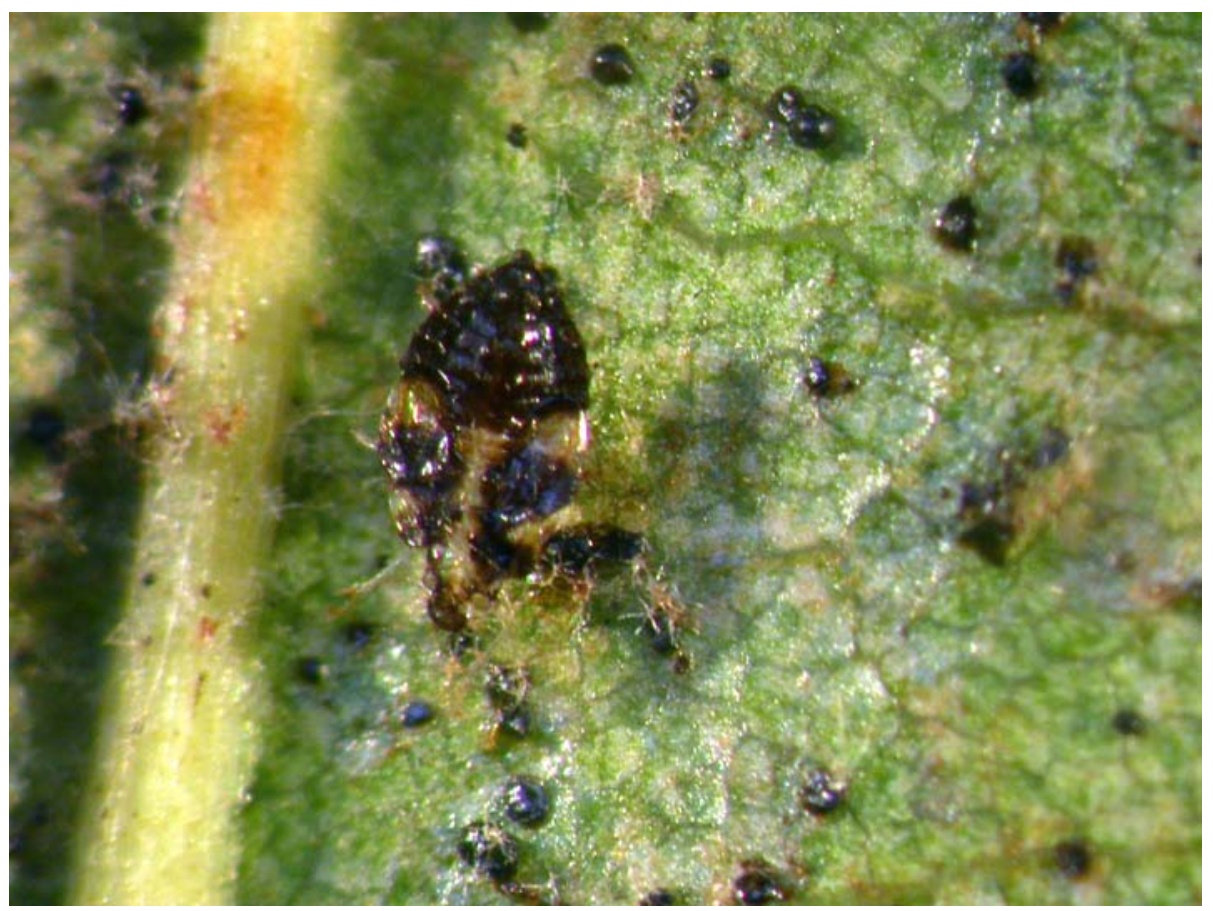

Fig. 1 - Exuvia of nymph of Corythucha ciliata and insect droppings on lower side of leaf of Platanus $\times$ acerifolia.

\section{Methods}

\section{Specimen and morphology}

Leaves of Platanus $\times$ acerifolia were collected in an avenue with several mature individuals. Because the trees were high, leaves could be collected by hand only exceptionally from lowermost branches. The leaves were examined with a hand-lens for the presence of mildew symptoms and studied with a dissecting microscope. Fungal material on a fallen leaf was mounted in 5-10\% aqueous $\mathrm{KOH}$ for study with a light microscope. Because of the sparse material, only ten ascomata and few conidiophores and conidia were measured without statistical treatment. The specimen was deposited at the fungal collection of National Museum of Natural Science, Taichung, Taiwan (TNM).

\section{Results}

Young leaves and leaves infected by parasitic insects show conspicuous white patches composed of plant trichomes (Fig. 2). Several leaves were strongly affected by the Sycamore Lace Bug Corythucha ciliata, which could be concluded by the presence of many black honeydew droplets and exuviae of the larvae (Figs 1, 3). Though the same site was investigated for ca. ten min each of three subsequent days, only one leaf carrying the powdery mildew Erysiphe platani was found.

Erysiphe platani (Howe) U. Braun and S. Takam., Schlechtendalia 4: 12 (2000). Figs 3-4

Hyphae 2-3 $\mu \mathrm{m}$ wide, appressoria lobed. Ascomata and conidia formed on lower side of leaf. Ascomata yellow when young and becoming black during maturation. Mature ascomata 107-130 $\mu \mathrm{m}$ diam., cells of ascoma wall irregular, 9-20 × 6-13 $\mu \mathrm{m}$, covered by 7-19 up to 4 times dichotomously branched appendages with brown base and 0-3-septa, ca. 140-250 $\mu \mathrm{m}$ long and 6-8 $\mu \mathrm{m}$ wide. Asci $4-8$, saccate, 48-65 × 29-45, with 2-5 ascospores. Ascospores ovoid or oblong, $21-23 \times 13-14 \mu \mathrm{m}$. Conidiophores verrucose, $120-215 \times 6-12 \mu \mathrm{m}$, 3-septate. Conidia reticulate, 30-38 × 16-21 $\mu \mathrm{m}$, germinating at one end with a hypha; germination with appressoria formation not found.

Known distribution (according to ISC 2011) - America, Asia, Australia, Europe: Bulgaria, France, Germany, Greece, Italy, Montenegro, Portugal, Romania, Serbia, Slovakia, Spain, Switzerland, Ukraine, United Kingdom.

Material examined - Germany, Hessen, Frankfurt am Main, Miquelallee with plantations of Platanus $\times$ acerifolia, on lower side of fallen leaf of $P$. $\times$ acerifolia, 3 August 2011, R. Kirschner 3530 (TNM). 


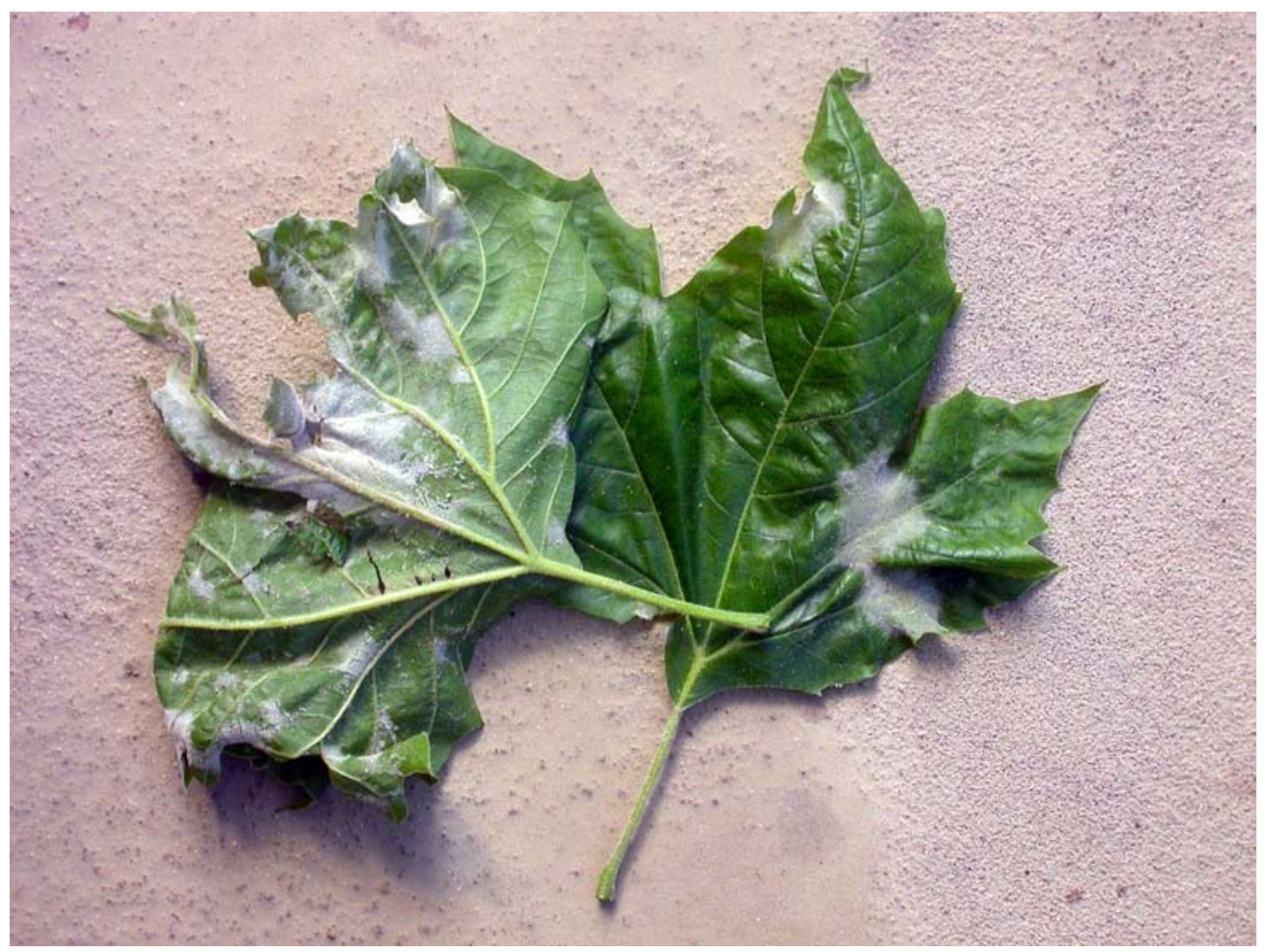

Fig. 2 - Leaves of Platanus $\times$ acerifolia with white patches formed by leaf trichomes resembling powdery mildew colonies.

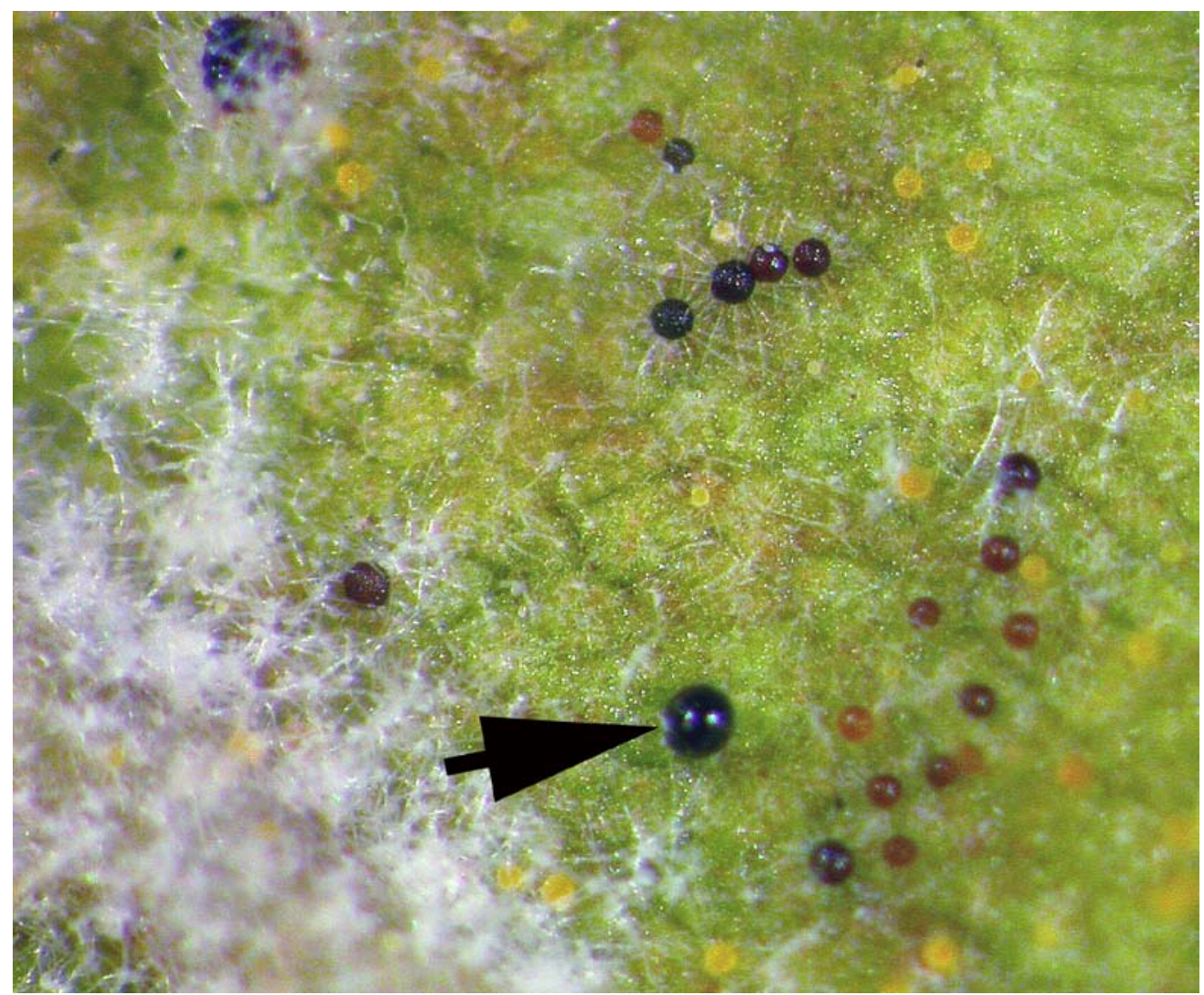

Fig. 3 - Ascomata of Erysiphe platani in different stages of development from yellow to black on lower side of leaf. Note white patches formed by leaf trichomes (lower left corner) and the black dropping of Corythucha ciliata (arrow) resembling a mature ascoma. 


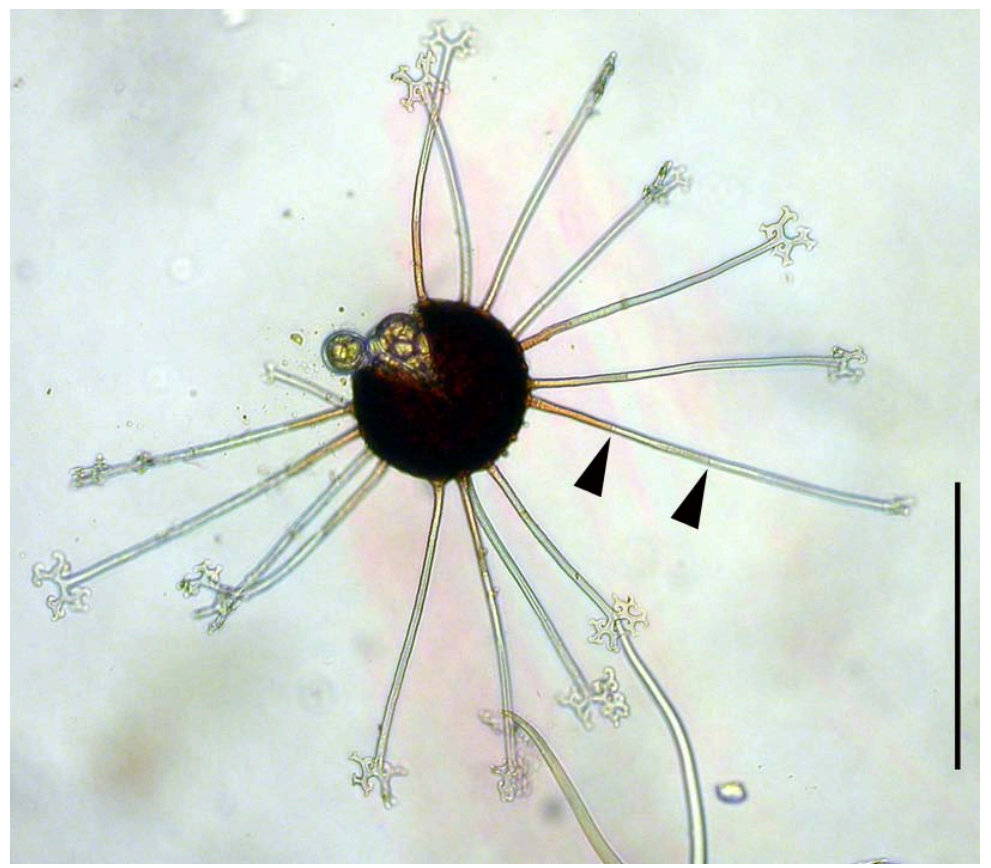

Fig. 4 - Mature, slightly squashed ascoma of Erysiphe platani in the light microscope. Note the brown bases of appendages and presence of septa (arrowheads). Scale Bar $=200 \mu \mathrm{m}$.

Note - The presence of the powdery mildew was obscured because the symptoms caused by the bug Corythucha ciliata and leaf areas covered by dense white trichomes produced by the plant (Fig. 3).

\section{Discussion}

Ascomata and conidia can be dispersed by wind and accumulate on non-host substrates (Takamatsu 2004). Records concerning mildews of very heterogeneous reliability in the internet without investigation of the origin of propagules can, therefore, not be considered here. Though only one leaf with few material of the powdery mildew was found, accidental wind-spread of mature ascomata and conidia of similar Erysiphe species from other hosts onto the leaf of $P . \times$ acerifolia (where they might have been caught by the trichomas) can be excluded, because young yellow ascomata were also found on the leaf and because of the associated conidiophores. For detailed morphological descriptions of the species in Europe see for the teleomorph Pastirčáková \& Pastirčák (2008) and for the anamorph Bolay (2005) and Pastirčáková \& Pastirčák (2006). The range of the few measurements possible with the sparse material fits generally into the ranges given in the literature, except for the slightly larger upper range of the ascomata (up to $130 \mu \mathrm{m}$ ). Other differences are the presence of up to 3 septa per appendage (0-1 reported in Braun 1987, Pastirčáková \& Pastirčák 2008) and of up to 8 asci per ascoma (up to 6 reported in Braun 1987, Pastirčáková \& Pastirčák 2008).

The spread of E. platani to Germany might be related to climate change, because in Europe the fungus has hitherto been known from countries south of Germany, mainly south and southeast Europe (ISC 2011). This situation is comparable to that of the invasive bug also introduced first in south Europe and gradually migrating towards the north. In contrast to the fungus, however, experimental evidence for preference of higher temperatures exists only for the bug (Ju et al. 2009). Similarly to several other invasive species of Erysiphales that often reproduce only asexually for a period of several years after being introduced (Kirschner 2010), E. platani in Europe was first known to reproduce by conidia only (Braun 1987, Bolay 2005, Pastirčáková \& Pastirčák 2006), and also by ascospores for the first time in 2003 in Montenegro, then 2008 in Hungary (Pastirčáková \& Pastirčák 2008), and now in Germany. Due to the presence of the sexual stage which is more adapted to overwintering than the asexual stage, more and seasonally earlier inoculum of the pathogen can be predicted for the following years. Because of the continued spread of E. platani in Europe, in new plantations of $P . \times$ acerifolia attention 
should be given to select cultivars with higher resistance against E. platani. Such cultivars already exist, such as "Yarwood" (Santamour \& McArdle 1986).

The bug C. ciliata produces conspicuous symptoms in form of numerous minute black, shiny droplets of honeydew on the lower side of leaves. Though being generally larger than the ascomata of $E$. platani, these droplets overlap in size and obscure the presence of the ascomata.

Young leaves of Platanus spp. are covered by a white layer formed by dense trichomes that gradually disappear during maturation (Yarwood \& Gardner 1970, Carpenter et al. 2005). Hairs on both sides are equal in length in $P$. $\times$ acerifolia, being about $500 \mu \mathrm{m}$, whereas the conidiophores of E. platani (as Microspharea alni) are about $100-200 \mu \mathrm{m}$, i.e. more than 20\% shorter than the hairs (Yarwood \& Gardner 1970). Mycelium and conidiophores growing between trichomes, therefore, cannot be differentiated from the trichomes macroscopically. Shedding off of the trichomes is often delayed in sunken leaf areas which may particularly remain even after leaf maturation due to contortion induced by parasitic arthropods. These white layers on leaves can easily been mistaken as colonies of the powdery mildew.

A further problem is concluded from the fact that E. platani was found on only one fallen leaf. Perhaps the heavy impact of the bug prevents the fungus from rich development. Many potential host trees could be checked for the presence of the fungus, but have a considerable height so that the leaves of the crown cannot be investigated without any additional tools.

Gathering specimens from high tree crowns, excluding identification of merely wind-blown propagules, and disguise of ascomata by insect droppings and of conidiophores by trichomes all need to be taken into account in detecting this powdery mildew.

\section{Acknowledgements}

Laboratory facilities were kindly provided by Meike Piepenbring, Goethe University Frankfurt am Main, Germany. This work was financed by the National Science Council of Taiwan (100-2621-B-008-001-MY3). Jascha
Weisenborn is thanked for providing the name of the bug and Markus Scholler for the information on the parallel preparation of a manuscript about detailed records from Germany.

\section{References}

Bolay A. 2005 - Les oïdiums de Suisse (Erysiphacées). Cryptogamica Helvetica 20, $1-176$.

Braun U. 1987 - A monograph of the Erysiphales (powdery mildews). Beihefte zur Nova Hedwigia 89, 1-700.

Carpenter RJ, Hill GS, Jordan JS. 2005 - Leaf cuticular morphology links Platanaceae and Proteaceae. International Journal of Plant Science 166, 843-855.

ISC. 2011 - Invasive Species Compendium, CABI. http://www.cabi.org/isc/

Ju RT, Wang F, Li B. 2009 - Effects of temperature on the development and population growth of the sycamore lace bug, Corythucha ciliata. Journal of Insect Science, 16. Available online: insect science.org/11.16

Kirschner R. 2010 - First record of Erysiphe magnifica on lotus, a host outside the Magnoliales. Mycological Progress 9, 417-424.

Pastirčáková K, Pastirčák M. 2006 - The anamorph of Erysiphe platani on Platanus hispanica in Slovakia. Mycotaxon 97, 189-194.

Pastirčáková K, Pastirčák M. 2008 - Erysiphe platani causing powdery mildew of London Plane in Hungary. Acta Phytopathologica et Entomologica Hungarica 43, 31-36.

Santamour FS, McArdle AJ. 1986 - Checklist of cultivated Platanus (planetree). Journal of Arboriculture 12, 78-83.

Takamatsu S. 2004 - Phylogeny and evolution of the powdery mildew fungi (Erysiphales, Ascomycota) inferred from nuclear ribosomal DNA sequences. Mycoscience 45, 147-157.

Yarwood CE, Gardner MW. 1970 - Leaf surface and leaf hairs affect length of conidiophores of Erysiphaceae. Mycologia 62, 707-713. 